УДК 349.6:504.174:546.49 (477)

DOI https://doi.org/10.32837/pyuv.v2i3(28).348

\author{
О. М. Шуміло

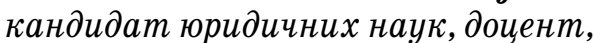 \\ доиент кафедри правового забезпечення господарської діяльності \\ Харківського національного університету внутрішніх справ
}

\title{
ДО ПИТАННЯ ПРАВОВОЇ ОХОРОНИ ДОВКІЛЛЯ ВІД ЗАБРУДНЕННЯ РТУТТЮ
}

Здавна люди надавали ртуті магічної сили, бо цей метал за кімнатної температури перебуває у стані рідини. Але науковим підтвердженням теорії найбільшого вимирання на планеті, яке сталося 252 мільйони років тому, стало те, що вчені по всьому світу знаходять частинки ртуті у відкладеннях того часу. Ця речовина з'явилася у повітрі після згорання великих запасів вугілля і потрапила у водойми. Його називають масовим пермським вимиранням, або великим вимиранням i, на думку фахівців з університету Цинциннаті та Китайського університету геологічних наук, воно сталося через велике виверження вулканів і випаровування ртуті [1].

У недавньому минулому в Україні працював на базі Микитівського ртутного родовища [2] у районі міста Горлівки Донецької області Микитівський ртутний комбінат (на сьогодні родовище законсервовано і фактично не експлуатується з 1991 р.) [3]. Мінеральний склад Микитівського ртутного родовища характеризується промисловими сортами штокверкових пластових лінзоподібних тіл, які містять до $30 \%$ ртуті [4]. Результатом видобування ртуті стало те, що Микитівське рудне поле стало територією екологічного лиха за вмістом ртуті в об'єктах довкілля. Унаслідок розробки ртутних родовищ відвали та відходи мають високу концентрацію ртуті - 5-45 мг/кг (у середньому 10-15 мг/кг), що перевищує фоновий вміст $(0,037$ мг/кг) у сотні разів [5].

За даними Організації Об’єднаних Націй (далі - OOH), уже в нинішньому XXI ст. забруднення ртуттю стане найгострішою проблемою для жителів Землі. Однією з наболілих проблем $є$ утилізація ртуті та ртутьвмісних відходів (далі РВB) [6]. Всесвітня організація охорони здоров'я (далі - В003) наголошує, що ртуть є одним із найбільш поширених та небезпечних токсикантів навколишнього середовища, належить до першого класу надзвичайно отруйних речовин [7].

Більшість робіт, присвячених проблемі охорони довкілля від забруднення ртуттю, виконувались в інших наукових галузях, а саме безпеки життедіяльності. Аналіз публікацій у сфері екологічного права свідчить, що проблемам забруднення ртуттю приділялася увага у працях таких учених, як: А. Гетьман, Ю. Шемшученко, А. Соколова. Проте здебільшого вони розглядали за- гальні питання охорони довкілля та забезпечення екологічного контролю в цій сфері.

Метою дослідження є аналіз світового досвіду щодо правової охорони довкілля від забруднення ртуттю таперспектив його використання в Україні.

Аналізуючи міжнародне законодавство, яке регулює поводження із ртуттю, варто зазначити, що європейські країни відмовляються від ртуті. Наприклад, органи влади в Норвегії та Швеції ввели законодавчу заборону на використання ртуті у виробництві, а також на її імпорт і експорт. Така ж заборона мала набрати чинності у Сполучених Штатах Америки ще у 2010 p.

На виконання міжнародних зобов'язань України, що випливають з її участі в Базельській конвенції про контроль за транскордонними перевезеннями небезпечних відходів та їх видаленням (1989 р.) [8], і з метою забезпечення дотримання вимог екологічної безпеки під час транскордонних перевезень небезпечних відходів Кабінет Міністрів України затвердив: Положення про контроль за транскордонними перевезеннями небезпечних відходів та їх утилізацією/видаленням; Жовтий перелік відходів; Зелений перелік відходів [9]. У цьому акті зазначено, що ртуть та сполуки ртуті належать до категорії відходів, які підлягають регулюванню і віднесені до Жовтого переліку відходів.

Відповідно до Директиви Європейського парламенту та Ради Європейського Союзу «Про відходи» (2008/98/ЄС від 19 листопада 2008 р.), класифікація відходів як «небезпечні відходи» повинна базуватись на законодавстві Співтовариства про хімікати, зокрема, що стосується класифікації препаратів як небезпечних, включаючи граничні значення концентрації цих препаратів. Небезпечні відходи мають регулюватися суворими специфікаціями, щоб запобігти (або обмежити), наскільки це можливо, потенційним негативним для людського життя ефектам, що виникли через неналежне поводження з такими відходами. Окрім того, треба дотримуватись системи, за якою відходи та небезпечні відходи класифікуються відповідно до списку видів відходів, складеного востаннє рішенням Комісії (2000/532 ЄС від 3 квітня 2000 р.), що встановлюе список відходів згідно зі ст. 1 (а) Директиви Ради 75/442/ЄС «Про відходи», та рішенням Ради 94/904/ЄС, що 
встановлює список небезпечних відходів згідно зі ст. 1 (4) Директиви Ради 91/689 ЄС «Про небезпечні відходи (OBL 226.6.9.2000.С.3)».

Аналізуючи євроінтеграційні процеси, варто зазначити, що в Україні вносяться зміни до законодавства, яке регламентує поводження із ртуттю. Відповідно до р. 3 Основних засад (стратегіï) державної екологічної політики України на період до 2020 р. [10], п. 1701 Плану заходів з виконання Угоди про асоціацію між Україною, з однієї сторони, та Європейським Союзом, європейським співтовариством з атомної енергії і їхніми державами-членами, з іншої сторони[11], з метою вдосконалення системи моніторингу якості атмосферного повітря в Україні затверджено Порядок здійснення моніторингу за вмістом миш'яку, кадмію, ртуті, нікелю та поліциклічних ароматичних вуглеводнів в атмосферному повітрі [12]. Згідно iз п. 5 р. III зазначеного Порядку, для оцінки якості атмосферного повітря щодо вмісту ртуті цільові показники й інші критерії оцінки не застосовують (на відміну від миш'яку, кадмію, нікелю і поліциклічних ароматичних вуглеводнів) унаслідок належності ртуті та її сполук до надзвичайно токсичних речовин (1 клас небезпеки). У цьому документі закріплено особливу небезпеку ртуті як токсичної речовини.

Законом України «Про Загальнодержавну програму поводження 3 токсичними відходами» затверджена Загальнодержавна програма поводження $з$ токсичними відходами [13]. Цією Програмою визначено два пілотні проєкти, пов'язані з очищенням від залишків ртуті промислових об'єктів: проведення заходів щодо рекультивації забруднених ртуттю полів фільтрації казенного заводу «Імпульс» (м. Шостка); проведення санації забрудненої ртуттю території ВАТ «Радикал» (м. Київ). Передбачалися також розроблення і дослідно-промислова апробація технології знешкодження й утилізації відходів, що містять ртуть, ВАТ «Микитівський ртутний комбінат». Приділяється увага ртуті в Законі України «Про ратифікацію Протоколу про реєстри викидів та перенесення забруднювачів», що визначає серед забруднювачів ртуть та її сполуки (як Hg) [14].

Податковий кодекс (далі - ПК) України [15] окремо передбачає ставки податку за розміщення відходів у спеціально відведених для цього місцях чи на об'єктах. Згідно із пп. 1 п. 1 ст. 246 ПК України, ставка податку за розміщення окремих видів надзвичайно небезпечних відходів, а саме обладнання та приладів, що містять ртуть, елементи 3 іонізуючим випромінюванням, - 865,47 грн за одиницю. Ставку податку за викиди в атмосферне повітря забруднюючих речовин стаціонарними джерелами забруднення, згідно з п. 1 ст. 243 ПК України, а саме ртуті та її сполук, визначено в розмipi 103931,28 грн за 1 т.
Кабінетом Міністрів України затверджено Технічний регламент обмеження використання деяких небезпечних речовин в електричному та електронному обладнанні [16], до таких речовин у ньому віднесена ртуть.

Національна комісія, що здійснює державне регулювання у сферах енергетики та комунальних послуг, затвердила Порядок опублікування інформації про частку кожного джерела енергії, використаного для виробництва електричної енергії, та вплив на навколишнє природне середовище, спричинений виробництвом електричної енергії [17]. Виробник оприлюднює інформацію про вплив на навколишнє природне середовище, спричинений виробництвом електричної енергії, за відповідною формою, шляхом розміщення даних на власному вебсайті. Серед викидів в атмосферне повітря мають визначатися ртуть та її сполуки.

Перед Україною зараз стоїть дилема переробки РВВ без забруднення довкілля. Адже за радянських часів РВВ, які утворювалися на території Радянського Союзу, централізовано перероблялися на Микитівському ртутному комбінаті. Існувала відпрацьована система збору, обліку, транспортування і переробки ртутьвмісних відходів. Щорічно перероблялося до 205 тисяч тонн РВВ дванадцяти найменувань, із цієї сировини вироблялося до 400 тонн товарної ртуті. Як результат, дослідження вмісту ртуті й інших хімічних елементів у рудах Микитівського рудного поля, хвостосховищах (хвости) Микитівського ртутного комбінату та території поблизу комбінату щодо сумарного показника забруднення грунтів ртуттю свідчить, що ці території належать до категорії помірно небезпечних [18]. Помірно небезпечний стан територій визначається в діапазоні оцінок системи умовних показників ушкодженості біосистем від 0,251 до 0,500 за «середнього» рівня ушкодженості біосистем і «задовільно-загрозливого» їхнього стану. Рекомендується нормуючий періодичний регламентний контроль таких територій [19]. Поблизу Микитівського ртутного комбінату вміст випарів ртуті становить від 155-300 до 1 427-1 680 мг/л, що є причиною ртутної інтоксикації жителів цього району, підвищеної захворюваності, дитячої смертності. У грунті навколишньої території, відстійнику i золі рослин виявлено концентрації ртуті, що перевищують фонові в 10-15 разів. Вміст металу в підземних водах у районі Микитівського ртутного комбінату у 20-30 разів перевищує ГДК.

Подібна проблема належного утримання хімічно небезпечного об'єкта та зберігання небезпечних відходів на підприємстві існує і в Києві, яка склалася навколо ВАТ «Радикал». Майже 70 років тому почалася промислова діяльність заводу хімікатів по вулиці Червоноткацька, 61, на відста- 
ні приблизно 4 км від станції метро Лісова. Завод спеціалізувався на виробництві каустичної соди, хлору, хімічних засобів захисту рослин тощо. У 1994 р. підприємство із площею 67 га приватизували шляхом корпоратизації та перетворили на ВAT «Радикал». У результаті недосконалості технологічних процесів виробництва відбулося значне забруднення хімічними речовинами окремих територій заводу, що зазначили у столичному Мiністерстві надзвичайних ситуацій.

У період із 1996 по 1998 рр. через відсутність коштів і борги за енергоносії всі види виробництва на ВАТ «Радикал» було зупинено без дотримання відповідних норм і виконання необхідних регламентних робіт. А саме: небезпечні хімічні речовини залишили на підприємстві 3 порушенням вимог законодавства та без охорони. На сьогодні у грунті та шламонакопичувачах заводу знаходяться сполуки небезпечних речовин, які накопичувалися протягом тривалої роботи.

Постановою Арбітражного суду Києва від 4 серпня 2000 р. ВАТ «Радикал» визнали банкрутом, стосовно заводу почалася процедура ліквідації. Наприкінці 2002 р. господарським судом Києва було затверджено план санації ВАТ «Радикал». Загальну вартість комплексу робіт із санації території підприємства оцінили в 96 млн гривень. Фінансування витрат для проведення першочергових робіт та розробку технічно-економічного обгрунтування інвестиційних вкладів у санацію в обсязі 1,3 млн гривень здійснювали коштом Київської міської державної адміністрації, однак на сьогодні фінансування припинено.

Протягом 2001-2005 pр. із території ВАТ «Радикал» вивезли 127 тонн ртуті металевої, понад 1000 тонн забрудненого ртуттю обладнання та хімічних речовин різного класу небезпеки. Ртуть i шлами, які забруднено ртуттю, відправили на ТОВ «Микитртуть» у Горлівку Донецької області [20].

Планувалося у 2013 р. почати вивіз грунту, обладнання та металевих конструкцій, забруднених ртуттю (більше 200 тис. тонн). Програма була складена на п'ять років, вартість робіт становила 134 млн грн. Вивезення ртутьвмісних відходів «Радикала» планувалось до Горлівки (Донецька область), в обсязі 200 тис. тонн елементів, що містять ртуть, решту планувалося спрямувати на поховання за кордон, але вже був неприємний інцидент, коли повідомили, що мають намір вивозити відходи до Чехії, то місцеві природоохоронці перекрили кордон [21]. Потім цифри було скореговано, на Микитівський комбінат планувалося вивезти приблизно 130 тисяч тонн відходів, 120 тисяч 3 яких будуть поховані без переробки (низька концентрація ртуті), а 10 тисяч мали переробити шляхом термічної демеркуризації (бо висока концентрація ртуті) [22].
Станом на 2017 р. на території колишнього столичного заводу «Радикал» у деяких точках концентрація ртуті в повітрі перевищує гранично допустиму норму до 30 разів. Концентрація отруйної речовини у грунті в деяких місцях перевищує допустиму норму до 14,5 разів [23].

Оцінка стану навколишнього середовища та правового регулювання у сфері гарантування екологічної безпеки під час поводження із ртуттю потребують системного підходу. Треба законодавчо заборонити припинення видобутку ртуті, використання ртуті у видобутку корисних копалин та інших промислових процесах; забезпечити стимулювання використання чистих джерел енергії, які не спалюють вугілля, а також здійснення безпечного поводження, використання й утилізацію продукції і відходів, що містять ртуть.

У зв'язку із цим доцільним $є$ приєднання України до Мінаматської конвенції, адже Конвенція є багатосторонньою природоохоронною угодою, у якій розглядаються конкретні види діяльності людини, що спричиняють широкомасштабне забруднення ртуттю. Ратифікація цієї угоди допоможе скоротити глобальне забруднення ртуттю в майбутні десятиліття шляхом забезпечення контролю за викидами ртуті в атмосферу від вугільних електростанцій, промислових котлів, що працюють на вугіллі, деяких видів діяльності 3 виробництва кольорових металів, спалювання відходів та виробництва цементу.

\section{Jimepamypa}

1. New evidence suggests volcanoes caused biggest mass extinction ever by University of Cincinnati. April 15, 2019. URL: https://phys.org/news/2019-04evidence-volcanoes-biggest-mass-extinction.html.

2. Микитівське родовище ртуті. Українська радянська енциклопедія : у 12-ти т. / гол. ред. М. Бажан ; редкол. : О. Антонов та ін. 2-ге вид. Т. 9 : Поплужне Салуїн. Київ : Голов. ред. УРЕ, 1983.

3. Гірничий енциклопедичний словник : у 3 -х т. / за ред. В. Білецького. Донецьк : Східний видавничий дім, 2004. T. 3. 752 c. URL: https://uk.wikipedia.org/wiki/ Спеціальна:Джерела книг/966780478X.

4. Багатаев Р., Роговой В. Геологическое изучение и освоение Никитовских ртутных месторождений Донбасса (Украина). Москва : Научный мир, 2011. 182 с.

5. Панаіт Е. Розподіл ртуті у поверхневих відкладах США, Китаю, України та Росії. Пошукова та екологічна геохімія. 2015. № 1 (16). C. 15-18. URL: https://igmof.org.ua/sites/default/files/peg_15-15-18. pdf.

6. Дмитруха Т. Забруднення довкілля ртуттю - найгостріша екологічна проблема сучасності. Екологічна безпека таприродокористування. 2014. Вип. 15. C.46-52.URL:http://nbuv.gov.ua/UJRN/ebpk_2014_15_8.

7. Международная программа по химической безопасности. Официальный сайт BO03. URL: https://www.who.int/ipcs/assessment/public_health/ mercury/ru/.

8. Базельська конвенція про контроль за транскордонним перевезенням небезпечних відходів та їх видаленням від 22 березня 1989 р. Офіиійний вісник Украйни. 2018. № 93. Ст. 3092 . 
9. Про затвердження Положення про контроль за транскордонними перевезеннями небезпечних відходів та їх утилізацією/видаленням і Жовтого та Зеленого переліків відходів : постанова Кабінету Міністрів України від 13 липня 2000 р. за № 1120. Офіиійний віс ник України. 2000. № 29. Ст. 1217.

10. Про Основні засади (стратегію) державної екологічної політики України на період до 2020 р. : Закон України від 21 грудня 2010 р. № 2818-VI. Відомості Верховної Ради Украӥни. 2011. № 26. Ст. 218.

11. Про виконання Угоди про асоціацію між Україною, з однієї сторони, та Європейським Союзом, Європейським співтовариством з атомної енергії і їхніми державами-членами, з іншої сторони : постанова Кабінету Міністрів України від 25 жовтня 2017 р. № 1106. Офіиійний вісник України. 2018. № 24. Ст. 852.

12. Про затвердження Порядку здійснення моніторингу за вмістом миш'яку, кадмію, ртуті, нікелю та поліциклічних ароматичних вуглеводнів в атмосферному повітрі : наказ Міністерства внутрішніх справ України від 28 лютого 2018 р. № 154. Офіційний вісник Украӥни. 2018. № 35. Ст. 1251.

13. Про Загальнодержавну програму поводження з токсичними відходами : Закон України від 14 вересня 2000 р. № 1947-III. Відомості Верховної Ради України. 2000. № 44. Ст. 374.

14. Про ратифікацію Протоколу про реєстри викидів та перенесення забруднювачів : Закон України від 3 лютого 2016 р. № 980-VIII. Відомості Верховної Ради України. 2016. № 11. Ст. 122.

15. Податковий кодекс України (ред. 31 січня 2017 р.) № 2755 -VI від 2 грудня 2010 р. Офіuійний віс ник України. 2010. № 92. Ч. 1. Ст. 3248.

16. Про затвердження Технічного регламенту обмеження використання деяких небезпечних речовин в електричному та електронному обладнанні : постанова Кабінету Міністрів України від 10 березня 2017 р. № 139. Офіиійний вісник України. 2017. № 24. Ст. 683.

17. Про затвердження Порядку опублікування інформації про частку кожного джерела енергії, використаного для виробництва електричної енергії, та вплив на навколишнє природне середовище, спричинений виробництвом електричної енергії : постанова Національної комісії, що здійснює державне регулювання у сфеpax енергетики та комунальних послуг, від 26 квітня 2019 р. № 642. Урядовий кур’єр. 2019. № 88.

18. Панаіт Е. Вміст ртуті у грунтах навколо Микитівського ртутного комбінату. Пошукова та екологічна геохімія. 2014. № № 1-2. С. 40-43. URL: http://nbuv.gov.ua/UJRN/Pteg_2014 1-2 9.

19. Про затвердження методичнй рекомендацій «Обстеження та районування території за ступенем впливу антропогенних чинників на стан об'єктів довкілля з використанням цитогенетичних методів» : наказ Міністерства охорони здоров'я України від 13 березня 2007 р. № 116. URL: https://ips.ligazakon.net/ document/view/MOZ6793?an=5\&is no morph= false\&listen star $=$ true

20. МHC підтверджує наявність небезпечних хімічних речовин на занедбаному заводі в Києві : інтерв'ю голови МНС у місті Києві Віктора Босака 14 травня 2009 р. Корреспондент.net.URL:https://ua.korrespondent.net/ ukraine/836496-mns-pidtverdzhue-nayavnistnebezpechnih-himichnih-rechovin-na-zanedbanomuzavodi-v-kievi.

21. Мусор выбросят за границу. Государство нашло, куда деть токсичные отходы с киевского завода
«Радикал». Коммерсантъ Украина. 2012. № 164. С. 3. URL: https://www.kommersant.ru/doc/2046158.

22. Загрязненные ртутью отходы с киевского завода «Радикал» вывезут в Донецкую область. Корреспондент.net. 27.09.2012. URL: https://korrespondent. net/kyiv/1400012-zagryaznennye-rtutyu-othody-skievskogo-zavoda-radikal-vyvezut-v-doneckuyu-oblast.

23. Макаренко Ірина. Вміст ртуті у повітрі над столичним «Радикалом» перевищує норму в 30 разів. 06.07.2017. Українські Національні Новини. URL: https://www.unn.com.ua/uk/news/1674791-vmistr tuti - u-povitri-nad-stoly chny m-radykalomperevyshchuie-normu-v-30-raziv.

\section{Анотація}

Шуміло О. М. До питання правової охорони довкілля від забруднення ртуттю. - Стаття.

У статті розглянуто аспекти правової охорони довкілля від забруднення ртуттю, що здійснюється на міжнародному та національному рівнях. Досліджено проблему правового регулювання переробки ртутьвмісних відходів в Україні й утилізації забруднених ртуттю грунтів.

Встановлено, що позитивною стороною євроінтеграційних процесів є внесення змін до законодавства, яке регламентує поводження із ртуттю. Так, з метою вдосконалення системи моніторингу якості атмосферного повітря в Україні затверджено Порядок здійснення моніторингу за вмістом миш'яку, кадмію, ртуті, нікелю та поліциклічних ароматичних вуглеводнів в атмосферному повітрі.

Висвітлено зміни нормативно-правового характеру щодо оподаткування підприємств за розміщення відходів у спеціально відведених для цього місцях чи на об'єктах. Так, збільшення ставки податку за розміщення окремих видів надзвичайно небезпечних відходів, а саме обладнання та приладів, що містять ртуть, елементи 3 іонізуючим випромінюванням, суттєво збільшено, що дасть у подальшому позитивний ефект щодо збереження довкілля. Досліджено позитивну динаміку щодо збільшення ставки податку за викиди в атмосферне повітря забруднюючих речовин стаціонарними джерелами забруднення, а саме ртуті та їі сполук.

Доведено позитивні зміни в законодавстві, що регулюють поводження 3 токсичними відходами. Так, Загальнодержавною програмою поводження із токсичними відходами визначено два пілотні проєкти, пов'язані 3 очищенням від залишків ртуті промислових об'єктів: проведення заходів щодо рекультивації забруднених ртуттю полів фільтрації казенного заводу «Імпульс» (м. Шостка); проведення санації забрудненої ртуттю території ВАТ «Радикал» (м. Київ). Чинним законодавством передбачається розроблення і дослідно-промислова апробація технології знешкодження й утилізації відходів, що містять ртуть.

Запропоновано приєднання до Мінаматської конвенції, законодавчу заборону видобутку ртуті і використання ртуті у видобутку корисних копалин в Україні. Наголошено, що приєднання до Конвенції дозволить забезпечити контроль за викидами ртуті в атмосферу від вугільних електростанцій, промислових котлів, що працюють на вугіллі, деяких видів діяльності з виробництва кольорових металів, спалювання відходів та виробництва цементу.

Ключові слова: ртуть, навколишнє природне середовище, Мінаматська конвенція, ртутьвмісні відходи, небезпечні відходи, заборона ртуті. 


\section{Summary}

Shumilo O.M. On the issue of environmental legal protection from mercury pollution. - Article.

The article considers the aspects of international and national legal framework for protecting the environment from mercury pollution. The problem of regulating mercury-containing waste recycling and mercury polluted soil disposal in Ukraine has been studied.

It has been stated that the positive side of European integration is amending the legislation on mercury treatment. E.g., in order to improve the air quality monitoring system in Ukraine the Regulation on monitoring the content of arsenic, cadmium, mercury, nickel and polycyclic aromatic hydrocarbons in the atmosphere has been approved.

The legal amendments on taxation of businesses for the disposal of waste in specifically designated areas or facilities have been highlighted. Thus, the tax rate for the disposal of certain types of extremely hazardous waste, such as mercury-containing equipment and devices, ionizing elements, has been significantly increased, which will have a positive environmental impact in the future. The positive dynamics of the increase in the tax rate for air emissions of pollutants by stationary sources of pollution, namely mercury and its compounds, has been investigated.

The positive character of the amendments to the legislation on toxic waste disposal has been proved. E.g., the National Toxic Waste Management Program has identified two pilot projects on the treatment of mercury residues at industrial sites: holding events on remediation of mercury-contaminated filtration fields at the "Impulse" state plant (Shostka); sanation of the mercury-contaminated territory of "Radical" enterprise (Kyiv). The legislation in force provides for the development and pilot testing of a technology for demolition and disposal of mercury-containing wastes.

Accession to the Minamata Convention and a legal ban on using mercury for mining purposes in Ukraine has been proposed. It has been emphasized that signing the convention would ensure monitoring mercury emissions of coal-fired power plants, industrial coal fired boilers, certain non-ferrous metals, waste incineration and cement production activities.

Key words: mercury, environment, Minamata convention, mercury-containing waste, dangerous waste. 